\title{
A METHOD OF STUDY OF THE PULMONARY CIRCULATION IN FINGER CLUBBING
}

\author{
BY \\ L. CUDKOWICZ AND D. G. WRAITH \\ From the Department of Thoracic Medicine, St. Thomas's Hospital, London
}

(RECEIVED FOR PUBLICATION JULY 5, 1957)

Clubbing of the fingers and toes is an inconstant accompaniment of a variety of dissimilar lung diseases such as bronchiectasis, primary bronchial neoplasms, arteriovenous aneurysms, and empyema. Its incidence, therefore, would appear to be related to an additional abnormality which only occasionally complicates these diseases.

The possibility that this added abnormality is localized in the pulmonary circulation arises from a post-mortem study by Cudkowicz and Armstrong (1953a), who noted that in different lung disorders associated with clubbing of the fingers and toes pre-capillary anastomoses between the bronchial and pulmonary arteries existed in one or more lung lobes. Pre-capillary anastomoses between the two circulations do not occur in the normal human lung (Miller, 1947; Cudkowicz and Armstrong, 1951), but have been recognized in various lung disorders radiographically by Wood and Miller (1938) and particularly by Liebow, Hales, and Lindskog (1949) in bronchiectatic lungs. Liebow, Hales, Harrison, Bloomer, and Lindskog (1950) noted arterialized blood in the left pulmonary artery of a patient with total left-sided bronchiectasis during cardiac catheterization. Gilroy, Wilson, and Marchand (1951) found arterial blood in the pulmonary arteries of bronchiectatic lobes at operation before lobectomy. Finally Roosenburg and Deenstra (1954), using the cardiac catheter technique, observed increased oxygen saturations in blood samples taken from pulmonary artery branches to abnormal lobes.

In the present study, evidence of the presence of bronchopulmonary pre-capillary anastomoses was sought by means of catheterization of the lobar branches of the pulmonary arteries in 24 patients with marked finger and toe clubbing who attended the Department of Thoracic Medicine, St. Thomas's Hospital, London, for a variety of respiratory ailments. It is the purpose of this paper to record the methods employed, and to compare the results obtained with those obtained in patients who had normal fingers and toes.

\section{MATERIAL}

Drumstick clubbing was the one characteristic which the patients studied had in common. The wide variety of other features which they presented, including central cyanosis as well as normal arterial oxygen saturations, and painless expansion of the terminal phalanges of fingers and toes as well as obvious joint swellings, have been recorded elsewhere (Cudkowicz and Wraith, 1957).

The clinical diagnoses of 33 patients investigated are shown in the Table. Patients Nos. 13, 30, 31, 32 , and 33 with normal fingers and toes have also been included for control purposes. Patient No. 13 suffered from sarcoidosis, and since his chest radiographs resemble those of patient No. 12 with drumstick clubbing who also has sarcoidosis, it was thought that a comparison of the catheter findings in these two patients would be of particular interest.

\section{MeTHODS}

Catheterization of Branches of Pulmonary ARTERY.-The procedure of cardiac catheterization was explained to the patient beforehand, and to minimize anxiety 3 grains $(180 \mathrm{mg}$.) of sodium amytal were given orally one hour before study. A size 7 cardiac catheter was used on most occasions, which permitted, by virtue of its small diameter, careful placing in the pulmonary artery branches without occluding the lumina as well as sampling as far distally as possible. These distal wedge pressures and samples will be regarded as "pulmonary capillary" pressures and samples although we are aware of the possible fallacy of this definition (Editorial, Circulation Research, 1953).

BLOOD SAMPLING.-Routine samples were taken from the following sites, whenever technically possible, and the catheter positions were carefully checked by fluoroscopy before sampling: (1) right ventricle; (2) main pulmonary artery approximately $2 \mathrm{~cm}$. beyond the valve ; (3) both right and left main pulmonary arteries at about $4 \mathrm{~cm}$. from their origin ; (4) from such lobar branches as were entered about $4 \mathrm{~cm}$. from their origin; (5) from wedged positions at the periphery of the branches entered in position (4). 


\begin{tabular}{|c|c|c|c|c|c|c|c|c|c|c|c|c|}
\hline \multirow[b]{2}{*}{ No. } & \multirow[b]{2}{*}{ Age } & \multirow[b]{2}{*}{ Sex } & \multirow[b]{2}{*}{ Clinical Diagnosis } & \multirow{2}{*}{$\begin{array}{c}\begin{array}{c}\text { Right } \\
\text { Auricle }\end{array} \\
\begin{array}{c}\text { Pres- } \\
\text { sure } \\
(\mathrm{mm} . \\
\mathrm{Hg})\end{array}\end{array}$} & \multicolumn{2}{|c|}{$\begin{array}{c}\text { Right } \\
\text { Ventricle }\end{array}$} & \multicolumn{2}{|c|}{$\begin{array}{l}\text { Main } \\
\text { Pulmonary } \\
\text { Artery }\end{array}$} & \multicolumn{2}{|c|}{$\begin{array}{l}\text { Right } \\
\text { Pulmonary } \\
\text { Artery }\end{array}$} & \multicolumn{2}{|c|}{$\begin{array}{l}\text { Right Lower } \\
\text { Lobe Pulmonary } \\
\text { Artery }\end{array}$} \\
\hline & & & & & $\begin{array}{l}\text { Pres- } \\
\text { sure } \\
(\mathrm{mm} . \\
\mathrm{Hg})\end{array}$ & $\begin{array}{c}O_{2} \\
\text { Satura- } \\
\text { tion } \\
(\%)\end{array}$ & $\begin{array}{l}\text { Pres- } \\
\text { sure } \\
(\mathrm{mm} . \\
\mathrm{Hg})\end{array}$ & $\begin{array}{c}\mathrm{O}_{2} \\
\text { Satura- } \\
\text { tion } \\
(\%)\end{array}$ & $\begin{array}{l}\text { Pres- } \\
\text { sure } \\
(\mathrm{mm} . \\
\mathrm{Hg})\end{array}$ & $\begin{array}{l}\mathrm{O}_{2} \\
\text { Satura- } \\
\text { tion } \\
(\%)\end{array}$ & $\begin{array}{l}\text { Pres- } \\
\text { sure } \\
(\underset{\mathrm{Hg}}{\mathrm{mg}})\end{array}$ & $\begin{array}{l}\mathrm{O}_{2} \\
\text { Satura- } \\
\text { tion } \\
(\%)\end{array}$ \\
\hline $\begin{array}{l}1 \\
2 \\
3 \\
4\end{array}$ & $\begin{array}{l}57 \\
53 \\
59 \\
50\end{array}$ & $\begin{array}{l}\mathbf{M} \\
\mathbf{M} \\
\mathbf{M} \\
\mathbf{F}\end{array}$ & $\begin{array}{l}\text { Idiopathic basal pulmonary fibrosis .. } \\
\text { Pneumoconiosis } \\
\text { Idiopathic basal pulmonary fibrosis... } \\
\text { Pulmonary tuberculosis with large } \\
\text { apical cavities }\end{array}$ & & & & & & & & & \\
\hline $\begin{array}{l}5 \\
6\end{array}$ & $\begin{array}{l}56 \\
48\end{array}$ & $\begin{array}{l}\mathbf{M} \\
\mathbf{M}\end{array}$ & $\begin{array}{l}\text { Left upper lobe bronchus carcinoma } \\
\text {, main bronchus carcinoma }\end{array}$ & 83 & $\begin{array}{l}19 \\
36\end{array}$ & $\begin{array}{l}69 \\
76\end{array}$ & $\begin{array}{l}172 \\
324\end{array}$ & $\begin{array}{l}74 \cdot 6 \\
76 \cdot 2\end{array}$ & & & \begin{tabular}{l|l}
142 \\
No \\
record
\end{tabular} & $\begin{array}{l}72 \cdot 2 \\
76\end{array}$ \\
\hline $\begin{array}{l}7 \\
8 \\
9\end{array}$ & $\begin{array}{l}55 \\
50 \\
59\end{array}$ & $\begin{array}{l}\mathbf{M} \\
\mathbf{M} \\
\mathbf{M}\end{array}$ & $\begin{array}{lccc}\text { Pneumoconiosis. } & \text { Hypopituitarism.. } \\
\text { Pneumoconiosis } & \ldots & . & .\end{array}$ & 62 & $\begin{array}{l}214 \\
304\end{array}$ & $\begin{array}{l}69 \\
68 \cdot 2\end{array}$ & $\begin{array}{l}203 \\
265\end{array}$ & $\begin{array}{l}71 \\
68.9\end{array}$ & 163 & $68 \cdot 9$ & $\begin{array}{l}102 \\
137\end{array}$ & $\begin{array}{l}70 \\
90 \cdot 5\end{array}$ \\
\hline $\begin{array}{l}10 \\
11 \\
12 \\
13 \\
14\end{array}$ & $\begin{array}{l}40 \\
55 \\
28 \\
46 \\
55\end{array}$ & $\begin{array}{l}\mathbf{M} \\
\mathbf{M} \\
\mathbf{M} \\
\mathbf{M} \\
\mathbf{M}\end{array}$ & $\begin{array}{ccccc}\text { Sarcoidosis } & \cdots & \cdots & \cdots & . \\
,, & \cdots & \cdots & \cdots & . \\
\text { Sarcoidosis (control patient) } \\
\text { Right upper lobe fibrosis and bron- }\end{array}$ & $\begin{array}{r}83 \\
112 \\
102 \\
51\end{array}$ & $\begin{array}{l}235 \\
31 / 1 \\
244 \\
374\end{array}$ & $\begin{array}{l}59 \\
61 \cdot 3 \\
72 \cdot 1 \\
71 \cdot 8\end{array}$ & $\begin{array}{ll}24 & 5 \\
28 & 4 \\
28 & 4 \\
37 & 5\end{array}$ & $\begin{array}{l}59 \cdot 5 \\
62 \cdot 8 \\
74 \cdot 0 \\
71 \cdot 2\end{array}$ & 324 & 82 & $\begin{array}{l}224 \\
304 \\
525\end{array}$ & $\begin{array}{l}89.8 \\
81.8 \\
71 \cdot 8\end{array}$ \\
\hline $\begin{array}{l}15 \\
16 \\
17 \\
18\end{array}$ & $\begin{array}{l}56 \\
31 \\
26 \\
48\end{array}$ & $\begin{array}{l}\mathrm{M} \\
\mathrm{M} \\
\mathrm{F} \\
\mathrm{M}\end{array}$ & $\begin{array}{l}\text { chiectasis } \\
\text { Widespread bilateral bronchiectasis } \ldots \\
\text { Bilateral lower lobe bronchiectasis } \ldots \\
\text { Bronchiectasis of the lingula } \\
\qquad, ., \quad, \quad \text { lingula and left lower }\end{array}$ & $\begin{array}{r}9 / 3 \\
7 / 3 \\
124 \\
42\end{array}$ & $\begin{array}{l}312 \\
402 \\
655 \\
263\end{array}$ & $\begin{array}{l}66 \cdot 5 \\
71 \cdot 0 \\
74 \\
71 \cdot 4\end{array}$ & $\begin{array}{l:l}40 & 11 \\
42 & 10 \\
62 & 9 \\
23 & 7\end{array}$ & $\begin{array}{l}65 \cdot 5 \\
73 \cdot 3 \\
76 \cdot 2 \\
70 \cdot 8\end{array}$ & & & $\begin{array}{ll}37 & 10 \\
42 & 10 \\
23 & 6 \\
27 & 11\end{array}$ & $\begin{array}{l}67 \cdot 7 \\
87 \cdot 5 \\
85 \cdot 8 \\
71 \cdot 5\end{array}$ \\
\hline 19 & 48 & $\mathbf{M}$ & $\begin{array}{l}\text { lobe } \\
\text { Old calcified tuberculosis right lower }\end{array}$ & $8 / 4$ & 252 & $72 \cdot 3$ & 278 & $79 \cdot 8$ & & & 186 & $80 \cdot 7$ \\
\hline 20 & 66 & M & $\begin{array}{l}\text { lobe with recent bronchopleural } \\
\text { fistula } \\
\text { Segmental bronchiectasis in left lower }\end{array}$ & 194 & 283 & $\begin{array}{c}82 \\
\text { No }\end{array}$ & 285 & 82 & & & 174 & $\begin{array}{l}93(\text { at } \\
\text { op. } 92)\end{array}$ \\
\hline $\begin{array}{l}21 \\
22\end{array}$ & $\begin{array}{l}66 \\
60\end{array}$ & $\stackrel{M}{M}$ & $\begin{array}{l}\text { lobe and lingula } . \\
\text { Apical fibrosis and basal emphysema } \\
\text { Apical fibrocaseous tuberculosis and }\end{array}$ & $\begin{array}{r}122 \\
62\end{array}$ & $\begin{array}{l}38,4 \\
374\end{array}$ & $\begin{array}{l}\text { sample } \\
65\end{array}$ & $\begin{array}{l}364 \\
302\end{array}$ & $\begin{array}{l}79 \\
72\end{array}$ & 302 & 72 & $\begin{array}{l}3,26 \\
26: 1\end{array}$ & $\begin{array}{l}77 \\
77\end{array}$ \\
\hline 23 & 46 & $\mathbf{M}$ & $\begin{array}{l}\text { right lower lobe fibrosis } \\
\text { Emphysema of right middle lobe and }\end{array}$ & $5: 1$ & 302 & $67 \cdot 5$ & $27 / 5$ & $69 \cdot 5$ & & & 255 & $90 \cdot 0$ \\
\hline 24 & $\begin{array}{l}63 \\
50\end{array}$ & $\begin{array}{l}M \\
M\end{array}$ & $\begin{array}{l}\text { right lowerlobe and left basal fibrosis } \\
\text { Idiopathic pulmonary fibrosis } \\
\text {,, },,\end{array}$ & $\begin{array}{l}612 \\
622 \\
42\end{array}$ & $\begin{array}{l}322 \\
364 \\
222\end{array}$ & $\begin{array}{l}63 \cdot 4 \\
72 \\
68 \cdot 8\end{array}$ & $\begin{array}{l}306 \\
354 \\
206\end{array}$ & $\begin{array}{l}70 \cdot 2 \\
78 \cdot 9 \\
68 \cdot 8\end{array}$ & & & $\begin{array}{l}304 \\
426 \\
188\end{array}$ & $\begin{array}{l}90 \cdot 8 \\
88 \cdot 9 \\
93 \cdot 8\end{array}$ \\
\hline 26 & 45 & $\mathrm{~F}$ & pülmonale & & 351 & 628 & 338 & $63 \cdot 8$ & & & 195 & $83 \cdot 8$ \\
\hline $\begin{array}{l}27 \\
28\end{array}$ & $\begin{array}{l}51 \\
46\end{array}$ & $\begin{array}{l}M \\
M\end{array}$ & $\begin{array}{l}\text { "Emphysema " } \\
\text { Secondary bronchiectasis and atelec- } \\
\text { tasis of right middle lobe .. }\end{array}$ & 114 & 752 & 74 & 608 & 74 & 436 & $81 \cdot 1$ & 526 & $91 \cdot 1$ \\
\hline $\begin{array}{l}29 \\
30\end{array}$ & $\begin{array}{l}53 \\
42\end{array}$ & $\begin{array}{l}\mathrm{M} \\
\mathrm{M}\end{array}$ & "Emphysema" & 62 & 212 & $63 \cdot 0$ & 2) 2 & $65 \cdot 0$ & & & 204 & $71 \cdot 0$ \\
\hline $\begin{array}{l}31 \\
32\end{array}$ & $\begin{array}{l}50 \\
46\end{array}$ & $\begin{array}{l}\mathrm{F} \\
\mathrm{M}\end{array}$ & $\begin{array}{l}\text { lower lobe (control patient) } \\
\text { Mitral stenosis (control patient) } \\
\text { Interventricular septal defect (control }\end{array}$ & $\begin{array}{ll}82 & 2 \\
5 & 2\end{array}$ & $\begin{array}{l}172 \\
261\end{array}$ & $\begin{array}{l}80 \cdot 3 \\
64 \cdot 9\end{array}$ & $\begin{array}{l}183 \\
239\end{array}$ & $\begin{array}{l}80 \cdot 3 \\
66 \cdot 4\end{array}$ & 184 & $76 \cdot 3$ & $\begin{array}{l}214 \\
195\end{array}$ & $\begin{array}{l}76 \cdot 3 \\
65 \cdot 8\end{array}$ \\
\hline 33 & 44 & M & $\begin{array}{l}\text { patient) } \\
\text { Right basal emphysema (control }\end{array}$ & 103 & 302 & $81 \cdot 3$ & 246 & $80 \cdot 4$ & & & 223 & $76 \cdot 8$ \\
\hline & & & $\begin{array}{lllll}\text { patient) } & \ldots & \ldots & \ldots & \ldots\end{array}$ & 52 & 225 & $66 \cdot 2$ & 308 & $57 \cdot 8$ & & & 258 & $66 \cdot 2$ \\
\hline
\end{tabular}

Samples from position (5) were usually more saturated than the samples in the other four positions.

Errors in the method of sampling from the branches of the pulmonary artery were minimized by ensuring that the catheter did not obstruct these vessels. This was accomplished by (a) advancing the catheter tip into corresponding positions in at least two pulmonary artery branches so that free excursions of the tip with each systole were visible on fluoroscopy ; (b) establishing that the tracings of the pressures at these sites were similar in contour and arterial in type (Fig. 1); and (c) "wedging" the catheter subsequently farther peripherally until systolic excursions of the tip ceased and a "wedge pressure curve " emerged.

Pulmonary capillary sampling, in our experience, differed from that in unwedged positions by the greater pull needed on the plunger of the sampling syringe. The ease of obtaining ample samples more proximally contrasted with the comparative difficulty of extracting fully saturated capillary samples, which frequently were of quite small yield. This difference in the extraction technique, as well as the placing of the catheter tip and its behavour in systole in the two different positions, excludes, in our view, the possibility of samples taken from proximal positions in pulmonary artery branches deriving from aspirates of pulmonary capillaries. In six cases, Nos. 5, 13, 30 . 31,32 , and 33, blood samples were collected from corresponding unwedged positions in at least two lobes. In these samples the oxygen saturations were approximately similar and comparable with those found in the main pulmonary arteries. The finding of a higher saturation value in an unwedged position in a lobar pulmonary artery branch compared with lower values elsewhere suggests pre-capillary bronchopulmonary anastomoses in that lobe.

The blood analyses for oxygen saturation were carried out within two hours of sampling in a Haldane apparatus (Douglas and Priestley, 1948) 


\begin{tabular}{|c|c|c|c|c|c|c|c|c|c|c|c|}
\hline \multicolumn{2}{|c|}{$\begin{array}{l}\text { Right Lower Lobe } \\
\text { "Pulmonary } \\
\text { Capillary" }\end{array}$} & \multicolumn{2}{|c|}{$\begin{array}{c}\text { Left } \\
\text { Pulmonary } \\
\text { Artery }\end{array}$} & \multicolumn{2}{|c|}{$\begin{array}{l}\text { Left Lower Lobe } \\
\text { Pulmonary } \\
\text { Artery }\end{array}$} & \multicolumn{2}{|c|}{$\begin{array}{l}\text { Left Lower Lobe } \\
\text { "Pulmonary } \\
\text { Capillary" }\end{array}$} & \multicolumn{2}{|c|}{$\begin{array}{l}\text { Right Middle Lobe } \\
\text { "Pulmonary } \\
\text { Capillary" }\end{array}$} & \multicolumn{2}{|c|}{$\begin{array}{l}\text { Right Upper Lobe } \\
\text { Pulmonary } \\
\text { Artery }\end{array}$} \\
\hline $\begin{array}{l}\text { Pres- } \\
\text { sure } \\
(\mathrm{mm} . \\
\mathrm{Hg})\end{array}$ & $\begin{array}{c}\mathrm{O}_{2} \\
\text { Satura- } \\
\text { tion } \\
(\%)\end{array}$ & $\begin{array}{l}\text { Pres- } \\
\text { sure } \\
(\mathrm{mm} . \\
\mathrm{Hg})\end{array}$ & $\begin{array}{c}\mathrm{O}_{2} \\
\text { Satura- } \\
\text { tion } \\
(\%)\end{array}$ & $\begin{array}{c}\text { Pres- } \\
\text { sure } \\
(\mathrm{mm} . \\
\mathbf{H g})\end{array}$ & $\begin{array}{c}\mathrm{O}_{2} \\
\text { Satura- } \\
\text { tion } \\
(\%)\end{array}$ & $\begin{array}{l}\text { Pres- } \\
\text { sure } \\
\text { (mm. } \\
\mathrm{Hg})\end{array}$ & $\begin{array}{c}\mathrm{O}_{2} \\
\text { Satura- } \\
\text { tion } \\
(\%)\end{array}$ & $\begin{array}{l}\text { Pres- } \\
\text { sure } \\
(\mathrm{mm} . \\
\mathbf{H g})\end{array}$ & $\begin{array}{c}\mathrm{O}_{2} \\
\text { Satura- } \\
\text { tion } \\
(\%)\end{array}$ & $\begin{array}{l}\text { Pres- } \\
\text { sure } \\
(\mathrm{mm} . \\
\mathbf{H g})\end{array}$ & $\begin{array}{c}\mathrm{O}_{2} \\
\text { Satura- } \\
\text { tion } \\
(\%)\end{array}$ \\
\hline $4: 2$ & $94 \cdot 3$ & $15 / 2$ & $74 \cdot 6$ & \multicolumn{2}{|c|}{ At operation 78.2} & \multicolumn{2}{|c|}{ Not obtained } & & & & \\
\hline $\begin{array}{r}3 / 1 \\
15 / 6\end{array}$ & $\begin{array}{l}93 \cdot 8 \\
90 \cdot 9\end{array}$ & $25 / 2$ & $92 \cdot 1$ & & & & & & & & \\
\hline $\begin{array}{l:l}4 & 2 \\
7 & 2 \\
3 & 1\end{array}$ & $\begin{array}{l}89 \cdot 4 \\
96\end{array}$ & & & $\begin{array}{l}17 / 3 \\
30 / 8\end{array}$ & $\begin{array}{l}82 \cdot 8 \\
71 \cdot 3\end{array}$ & $4 / 2$ & 93.4 & & & & \\
\hline $\begin{array}{r}9 / 2 \\
93 \\
209 \\
41\end{array}$ & $\begin{array}{l}97.6 \\
87.5 \\
88.0 \\
93.0\end{array}$ & $\begin{array}{l}629 \\
22 / 9\end{array}$ & $\begin{array}{l}82 \\
81 \cdot 1\end{array}$ & $\begin{array}{ll}40 & 10 \\
28 & 9 \\
23 & 10\end{array}$ & $\begin{array}{l}85 \cdot 8 \\
82 \cdot 8 \\
91 \cdot 8\end{array}$ & 61 & 93.0 & 41 & 93 & 3612 & $81 \cdot 3$ \\
\hline 62 & $98 \cdot 4$ & & & $\begin{array}{r}247 \\
198\end{array}$ & $\begin{array}{l}96 \cdot 2 \\
82\end{array}$ & 62 & No sample & & & & \\
\hline $\begin{array}{l}8 / 1 \\
6 / 1\end{array}$ & $\begin{array}{l}\text { No sample } \\
\text { " },\end{array}$ & & & 326 & 97 & 101 & 97 & & & & \\
\hline $4 / 2$ & $97 \cdot 5$ & & & 225 & $74 \cdot 3$ & & & & & & \\
\hline $\begin{array}{r}12 / 2 \\
16 / 5 \\
7 / 1\end{array}$ & $\begin{array}{c}90 \cdot 8 \\
90 \cdot 1 \\
\text { No sample }\end{array}$ & $17 / 4$ & 69.9 & & & & 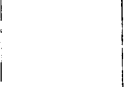 & & & & \\
\hline $\begin{array}{r}4: 2 \\
10 / 2\end{array}$ & $\begin{array}{l}86 \cdot 4 \\
94 \cdot 3\end{array}$ & 388 & $85 \cdot 0$ & 246 & $88 \cdot 2$ & 42 & No sample & & & & \\
\hline $4 / 1$ & No sample & & & & & & & & & & \\
\hline $\begin{array}{l}73 \\
41\end{array}$ & $\begin{array}{l}90 \cdot 0 \\
96 \cdot 8\end{array}$ & 204 & $76 \cdot 3$ & $\begin{array}{l}174 \\
216\end{array}$ & $\begin{array}{l}76 \cdot 3 \\
71 \cdot 8\end{array}$ & 41 & $91 \cdot 3$ & & & & \\
\hline 62 & No sample & & & 235 & $78 \cdot 3$ & $6 / 2$ & $94 \cdot 3$ & & & & \\
\hline 102 & 97.4 & & RML & 2011 & $66 \cdot 2$ & 92 & $85 \cdot 4$ & & & & \\
\hline
\end{tabular}

and the oxygen saturation was calculated from the oxygen content and capacity of the individual sample.

Pressure Recordings.-Pressures in the right auricle, right ventricle, main pulmonary artery, its branches, when entered, and at capillary level were recorded with a Sanborn electro-capacitance manometer (Rappaport and Sarnoff, 1949) and also observed together with the continuous electrocardiogram on a two-channel oscilloscope. The "wedge pressure" recordings were of the type described by Hellems, Haynes, and Dexter (1949) (Fig. 1). All pressures were referred to the level of the fourth right intercostal cartilage.

\section{RESUlTS}

An analysis of the results of the pressure records and oxygen saturations in the right heart and the pulmonary artery and its branches is shown in the Table. Unwedged samples from lobar branches of the pulmonary arteries showing saturations significantly above those of the main pulmonary artery are printed in italics.

Pressures and Oxygen Saturation Values in Right Heart.-The values in respect of right auricular pressures were of little specific significance, and their variation from the normal was in general associated with pulmonary hypertension, as seen in patient No. 16 whose right auricular pressure was $12 / 4 \mathrm{~mm} . \mathrm{Hg}$, and this was associated with a large "a" wave clinically.

Similarly, right ventricular pressures were raised in patients Nos. 15, 16, and 27, in whom there was evidence of pulmonary hypertension in the absence of right heart failure. The oxygen saturations in the right ventricular samples were within normal limits except for the values of $80.3 \%, 81.3 \%$, and $82 \%$ in patients Nos. 30,32 , and 19 respectively. 


\begin{tabular}{c|c|c|c}
\hline \multirow{3}{*}{ Site } & Pressure Tracing & $\begin{array}{c}\text { Pres- } \\
\text { sures } \\
(\mathrm{mm} . \\
\mathrm{Hg})\end{array}$ & $\begin{array}{c}\text { Oxygen } \\
\text { Satura- } \\
\text { tion } \\
(\%)\end{array}$ \\
\hline
\end{tabular}

Case No. 16, bilateral bronchiectasis, arterial $\mathrm{O}_{2}$ saturation $89.4 \%$
Right auricle

Right ventricle

Main pulmonary artery

Right lower lobe pulmonary

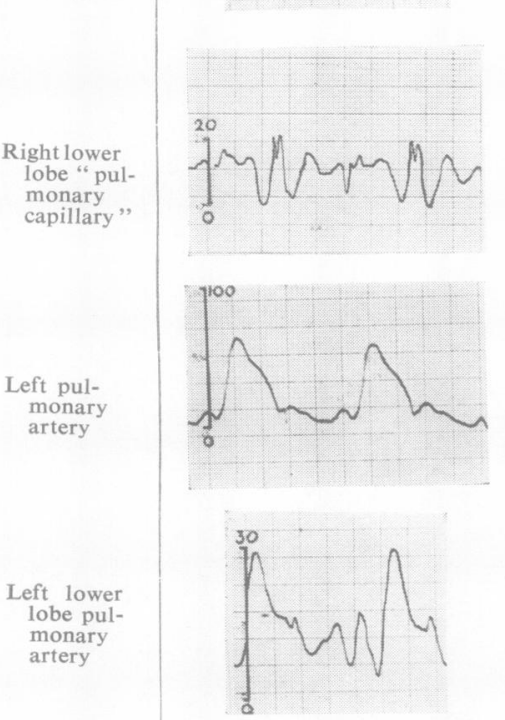

$12 / 4$
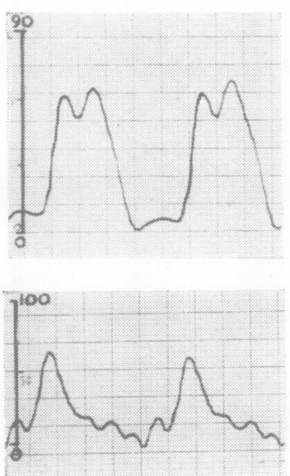

62

$76 \cdot 2$

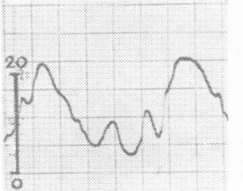

$20 / 9$

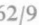

$28 / 9$
FIG, 1.-Pressure records and oxygen saturations at various levels in the right heart and pulmonary artery and its branches in bilateral and unilateral bronchiectasis compared with those in a control.
FIG. 1.-continued.

\begin{tabular}{l|c|c|c}
\hline \multirow{3}{*}{ Site } & & Pres- & Oxygen \\
& Pressure Tracing & sures & Satura- \\
& $(\mathrm{mm}$. & tion \\
& $\mathrm{Hg})$ & $(\%)$ \\
\hline
\end{tabular}

Case No. 18, lingular bronchiectasis, arterial $\mathrm{O}_{2}$ saturation $98.4 \%$
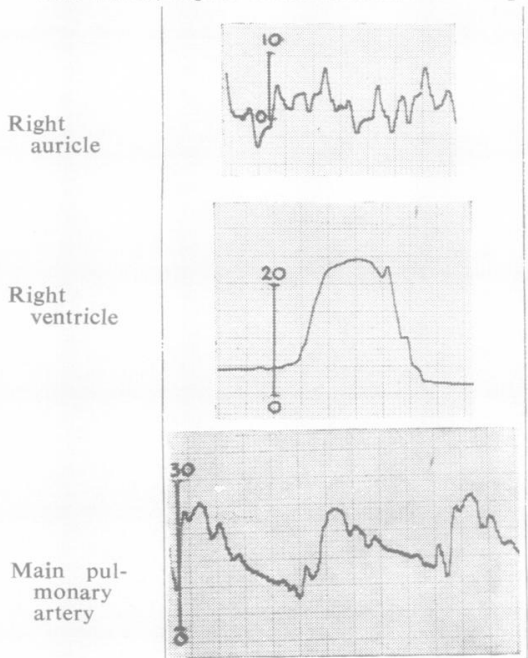

Right lower lobe pulmonary artery
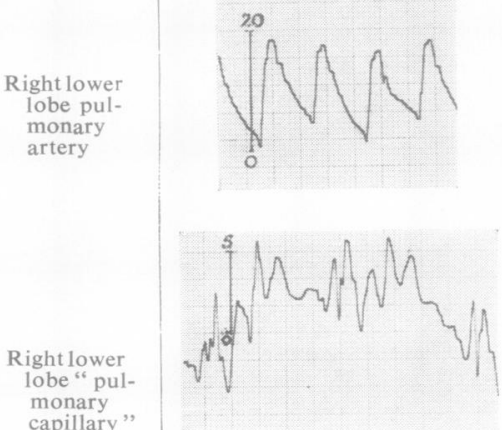
capillary "

$$
\begin{aligned}
& \text { Left lower } \\
& \text { lobe pul- } \\
& \text { monary } \\
& \text { artery }
\end{aligned}
$$

Left lower lobe "pulmonary capillary', 
FIG. 1.-continued.

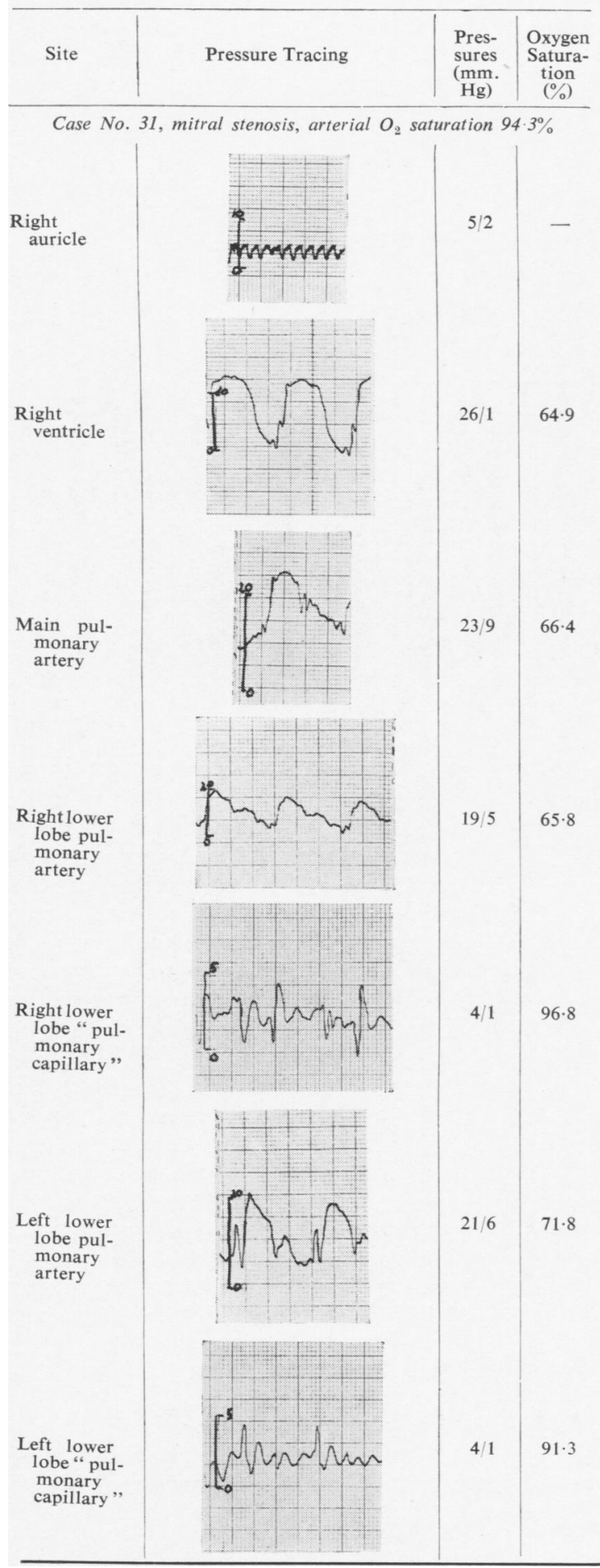

Pressures and Oxygen Saturation Values in Pulmonary ARTery and Branches.-The values for both pressure and saturation in the main pulmonary artery resembled those of the right ventricle. Analysis of the saturation figures of the branches of the pulmonary artery, however, shows that in 16 patients oxygen saturations were obtained from one or more branches which significantly exceeded those of the main pulmonary artery and right ventricle. In 12 patients high figures were noted in one branch only, whereas in Cases 11, 15, 16, and 27 high arterial oxygen saturations, exceeding $82 \%$, were obtained from two lobar branches of the pulmonary artery.

The pressures in the main and lobar branches of the pulmonary arteries were normal in 12 patients with high saturations in a single lobe (Fig. 2). In Cases 15, 16, and 27 the pulmonary artery systolic pressure was significantly raised in the main trunk, but fell towards the periphery. Cases 16 and 24 showed a rise in diastolic pressure towards the periphery (Fig. 3). No saturation anomalies were noted in the pulmonary artery branches of patients Nos. 13, 30, 31, 32, and 33. Case 13 suffered from sarcoidosis and had no clubbing, but his chest radiograph resembled that of patient 12 also suffering from sarcoidosis and showing marked clubbing. The latter patient showed a saturation abnormality in the right lower lobe. Case 30 had very doubtful clubbing, and, in view of the normal saturation values in the left lower lobe pulmonary artery, the diagnosis of arteriovenous aneurysm was revised to that of a varicose dilatation of the left lower lobe pulmonary artery. In Cases $11,17,18$, 19,20 , and 22 marked differences in oxygen saturation between samples taken at corresponding points in two different lobes could be demonstrated while the pressure tracings in all instances remained of the arterial type (see Fig. 2). In patients Nos. 5, 7, 21, and 29 no saturation abnormalities could be demonstrated in the single lobes which were explored, and failure of exploration of the other lobes precludes, therefore, adequate assessment of these cases. In four cases a raised pulmonary artery pressure was noted, and in Cases 15,16 , and 27 this was associated with bilateral pre-capillary bronchopulmonary anastomoses This rise in pressure was not associated with severe anoxia or heart failure. The arterial oxygen saturations in these three cases were $87.5 \%$, $89.4 \%$, and $94.3 \%$ respectively, while the oxygen saturations in two lobar branches of the pulmonary artery exceeded those of both the right ventricle and the main pulmonary artery respectively. 

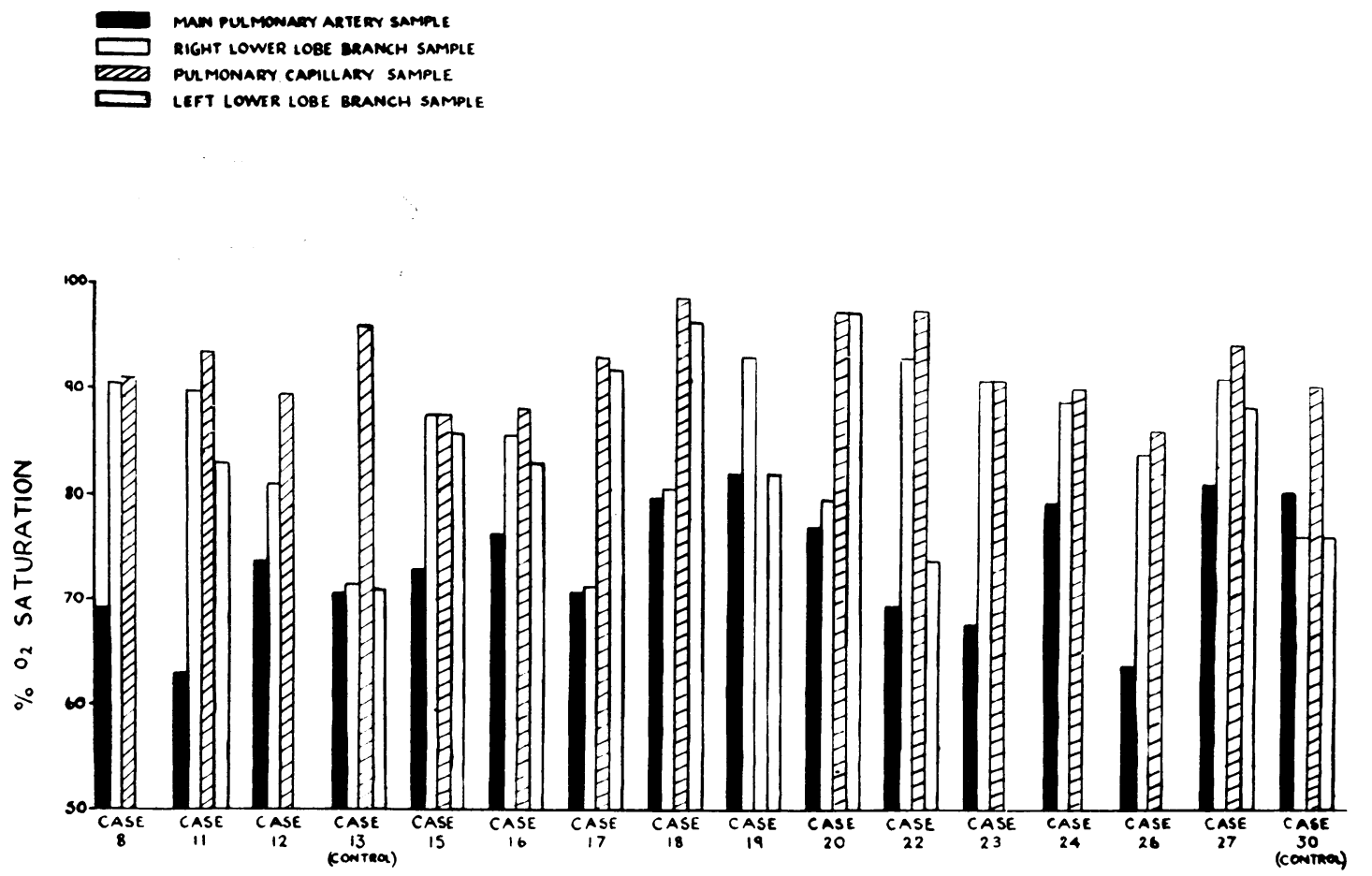

Fig. 2.-Summary of the results in 14 patients with finger clubbing and in two control patients (Nos. 13 and 30 ) in respect of oxygen saturation in (1) main pulmonary artery, (2) right lower lobe pulmonary artery, (3) left lower lobe pulmonary artery, (4) pulmonary capillaries.

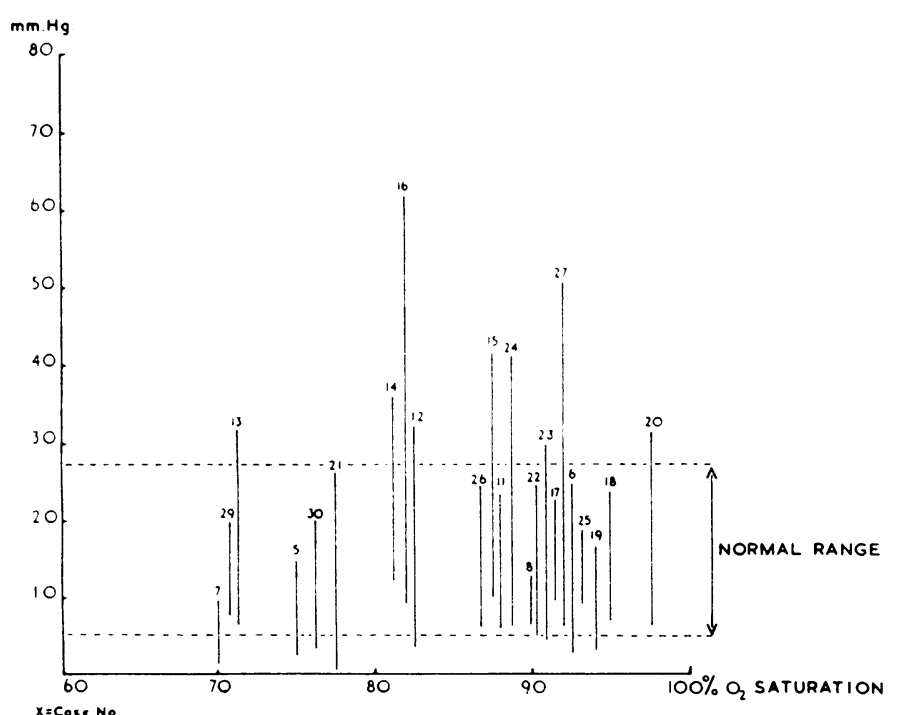

FIG. 3.-The relationship of pressure to the percentage oxygen saturation in the lobar branches of the pulmonary artery in 23 cases.

\section{Discussion}

It is not proposed to discuss the association of clubbing of the fingers in diseases outside the thorax such as listed by Mendlowitz (1942), as the variability of clubbing in common lung diseases alone poses its own problems. The mechanism of this phenomenon remains obscure, but a common denominator accompanying lung diseases which have become complicated by either hypertrophic osteoarthropathy or painless clubbing appears to be found in abnormal anastomoses between the bronchial and pulmonary arteries in one or more lobes. A similar vascular anomaly exists in those congenital heart diseases which are associated with atresia of the pulmonary arteries and was demonstrated in a case of transposition of the great vessels in which a deformity of the pulmonary valve was also present (Cudkowicz and Armstrong, 1952).

The identification of the vasculature in ordinary lung sections is difficult even in the normal human lung (Brenner, 1935) unless the bronchial or the pulmonary arteries have previously been injected with a fixable medium too coarse to traverse capillaries. This identification becomes even more 
difficult in the presence of pre-capillary anastomoses in abnormal lungs unless careful injection techniques have been employed. Hence the demonstration of anatomical abnormalities in lung vessels in cases of pulmonary hypertension is in itself not very helpful unless the circulations concerned have been adequately identified. McKeown (1952) has doubted if a relationship exists between the vascular changes in the pulmonary artery bed and pulmonary hypertension, and Whitaker (1956) expected changes in the walls of the pulmonary arteries only if the pressures are of the order of 50 to $70 \mathrm{~mm}$. $\mathrm{Hg}$. Abnormal communications between the bronchial and pulmonary arteries are now anatomically well recognized (Liebow and others, 1949; Marchand, Gilroy, and Wilson, 1950 ; Cudkowicz and Armstrong, 1953a, 1953b), but their clinical effects remain obscure. In the experimental field the flow through the collateral bronchial circulation after ligation of one pulmonary artery in the dog was found to exceed 1 1./sq.m./min. (Bloomer, Harrison, Lindskog, and Liebow, 1949) and was thought to burden the left ventricle. A similar conclusion was reached by Gray, Lurie, and Whittemore (1951), who studied the pulmonary collateral circulation in 10 patients with chronic lung disease. The application of the direct Fick principle is unlikely to shed an accurate light on the exact volumes of bronchial arterial blood reaching the pulmonary artery bed through pre-capillary anastomoses as this blood is already fully saturated, and other methods of study are necessary for accurate measurement. It is of some interest that three of our patients had pulmonary hypertension as well as evidence of pre-capillary anastomoses in at least two lung lobes. None of these patients suffered from severe anoxia or heart failure. Facilities for observing blood and alveolar $\mathrm{pCO}_{2}$ were, unfortunately, not available and hypercapnia may very well have been present. The finding of widespread bilateral pre-capillary anastomoses suggests yet another factor in the mechanism of pulmonary hypertension. The existence of these anastomoses throughout the periphery of the distorted pulmonary artery bed is calculated to raise the peripheral resistance of this circulation. This contrasts with patent ductus arteriosus where the augmented flow enters the pulmonary artery proximally and can be accommodated in the commodious pulmonary artery bed for long periods before arteriolar changes occur and pulmonary artery pressure rises. The demonstration of precapillary anastomoses between the bronchial and pulmonary arteries does not in itself explain the development of clubbing. Larger series of patients with clubbing require study before it can even be assumed that this anomaly in the lungs is invariably demonstrable. Patients with liver disease and clubbing may have a similar anomaly in the hepatic vasculature which would be more difficult to demonstrate. Common denominators in diseases associated with clubbing are not easily established, but this study suggests that in various lung diseases pre-capillary bronchopulmonary anastomoses constitute such a denominator. These anastomoses do not have to be extensive, and in small primary lung tumours associated with painful clubbing they exist only in the immediate vicinity of the growing tumour (Cudkowicz and Armstrong, 1953b). It is of interest that hypertrophic pulmonary osteoarthropathy subsides after resection of the lung tumour (Semple and McCluskie, 1955), presumably as a result of the excision of both anastomoses and the tumour. In our experience the severing of the vagus, as described by Hansen (1952), at the hilum did not reduce the measurable volume of the clubbed digit but appeared to abolish pain.

The method of catheterization of the branches of the pulmonary arteries to demonstrate bronchopulmonary anastomoses, as outlined in this study, is not beyond criticism, particularly in respect of blood sampling. Our saturation figures represent only an approximation to the truth, in the absence of a means of determining oxygen saturation at any one point in a branch of the pulmonary artery which does not require the aspiration of a sample through the catheter. Nevertheless, using a rigid sampling technique, fluoroscopic placing of the catheter tip and accurate pressure recording, we were able to aspirate nearly fully saturated blood samples from unwedged positions in lobes involved by disease which differed significantly from those obtained in corresponding positions in healthy lobes in the same patient. The inability to obtain saturated blood from unwedged positions in five control patients also precludes aspiration from pulmonary capillaries. Arterial blood sampled from a branch of the pulmonary artery through an unwedged catheter is, in our view, evidence of the existence of pre-capillary bronchopulmonary anastomoses.

\section{SUMMARY}

Bronchopulmonary pre-capillary anastomoses exist in certain lung disorders which become complicated by clubbing of the fingers. This vascular anomaly, which has been found in lungs at necropsy, has been sought in five control patients and 24 with drumstick clubbing of the fingers by 
means of catheterization of the right heart and the lobar branches of the pulmonary artery.

The pressures in the chambers of the right heart, main pulmonary artery, its lobar branches, and peripheral "wedged" positions and the oxygen saturations at these sites have been recorded.

The results in 16 successfully studied patients suggest that abnormally high oxygen saturations obtain in the pulmonary artery branches of abnormal lobes. In three instances this abnormality was present in at least two lobes and was associated with a raised pulmonary artery pressure, absence of congestive heart failure, and arterial oxygen saturations within normal limits. The significance of these findings is discussed.

We are indebted to Professor Sharpey-Schafer and Dr. Raymond Daley for provision of cardiac catheter facilities, and to Drs. H. J. Anderson and D. S. Cadman for permission to study the patients under their care. One of us (L.C.) wishes to thank the physicians at Yale University Medical School and. in particular, Dr. A. A. Liebow for his constructive criticism and Dr. F. D. Gray. Jr., and his technical staff for much help. We would also like to thank Mr. N. R. Barrett and Mr. G. Kent Harrison for obtaining blood samples at operation. and Miss $\mathbf{J}$.
Dewe, the medical artist, St. Thomas Hospital, and the Department of Medical Photography for their co-operation.

\section{REFERENCES}

Bloomer, W. E., Harrison, W., Lindskog, G. E., and Liebow, A. A (1949). Amer. J. Physiol., 157, 317.

Brenner, O. (1935). Arch. intern. Med., 56, 211.

Cudkowicz, L., and Armstrong, J. B. (1951). Thorax, 6, 343.

_- (1952). Brit. Heart J., 14, 374. (1953a). Brit. J. Tuberc., 47, 227

-

Douglas, C. G., and Priestley, J. G. (1948). Human Physiology. 3rd ed. Oxford University Press, London.

Editorial (1953). Circulat. Res., 1, 371 (Sept.).

Gilroy, J. C., Wilson, V. H., and Marchand, P. (1951). Thorax, 6. 137.

Gray, F. D., Lurie, P. R., and Whittemore, R. (1951). Yale J. Biol. Med., 23, 380.

Hansen, J. L. (1952). Acta med. scand., 142, Suppl. 266, p. 467.

Hellems, H. K., Haynes, F. W., and Dexter, L. (1949). J. appl. Physiol., 2, 24.

Liebow, A. A., Hales, M. R., and Lindskog, G. E. (1949). Amer. J.

Path., 25, 211 . Yale J. Biol. Med., 22, 637.

Mckeown, F. (1952). Brit. Heart J., 14, 25.

Marchand, P.. Gilroy, J. C., and Wilson, V. H. (1950). Thorax, 5, 207.

Mendlowitz, M. (1942). Medicine (Baltimore), 21, 269.

Miller, W. S. (1947). The Lung, 2nd ed. Thomas, Springfield,

Illinois.
Rappaport, H., and Sarnoff, S. J. (1949). Fed. Proc., 8, 130.

Roosenburg, J. G., and Deenstra, H. (1954). Dis. Chest, 26, 664.

Semple, T., and McCluskie, R. A. (1955). Brit. med. J., 1, 754.

Whitaker, W. (1956). Pulmonary Circulation and Respiratory Function. A Symposium held at Queen's College, Dundee, p. 18 University of St. Andrews. Livingstone, Edinburgh.

Wood, D. A., and Miller, M. (1938). J.thorac. Surg., 7. 649. 